\title{
Empty Streets, Speeding and Motor Vehicle Collisions during Covid-19 Lockdowns: Evidence from Northern Ireland
}

\author{
Sotiris Vandoros ${ }^{\mathrm{a}, \mathrm{b} *}$ and Fotis Papailias ${ }^{\mathrm{a}}$ \\ a King's College London, London, UK \\ ${ }^{\mathrm{b}}$ Harvard T.H.Chan School of Public Health, Boston MA, USA \\ *Correspondence to: $\underline{\text { s.vandoros@kcl.ac.uk }}$
}

\begin{abstract}
Covid-19 and lockdowns have had spillover effects on other health outcomes. Motor vehicle collisions (MVC) are likely to have been affected by the pandemic due to, among others, less traffic volume and speeding on empty streets. This paper studies the impact of the pandemic on MVCs in Northern Ireland. Using monthly data on injuries and deaths, we find a steep decline in slight and serious injuries compared to what would have been expected in the absence of the pandemic. However, we find no effect on the number of deaths. Based on data from speeding tickets, a plausible explanation for the differential effect on the number of injuries and deaths is speeding on empty streets during the pandemic.
\end{abstract}

Keywords: Covid-19; lockdown; motor vehicle collisions; speeding; injury; mortality

\section{Background}

Over 50 people lose their lives in Motor Vehicle Collisions (MVC) in Northern Ireland every year, and more than 700 are seriously injured. ${ }^{1}$ As Covid-19 has been affecting nearly all aspects of everyday activities, there are reasons to believe that the number of MVCs has also been affected by the pandemic, as outlined by plausible mechanisms put forward in a previous study. ${ }^{2}$

First, the impact on traffic volume may have an ambiguous effect on the number and severity of MVCs. People are likely to commute less due to lockdowns and due to being afraid of catching Covid-19. On one hand, less traffic volume means fewer vehicles at risk of collision. Higher unemployment rates observed during the pandemic ${ }^{3}$ also are likely to lead to

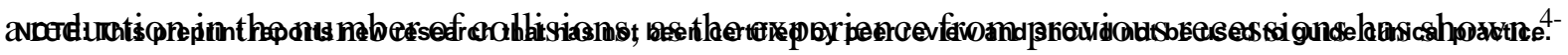


medRxiv preprint doi: https://doi.org/10.1101/2021.01.03.21249173; this version posted January 5, 2021. The copyright holder for this

preprint (which was not certified by peer review) is the author/funder, who has granted medRxiv a license to display the preprint in It is made available under a CC-BY-NC-ND 4.0 International license .

${ }^{5}$ On the other hand, less congested streets give an opportunity for speeding, which may affect the likelihood and severity of collision. ${ }^{6-7}$

Second, factors associated with the pandemic have had an impact on driving behaviour. Distraction, due to worrying about family members who are ill $^{8}$ or due to economic uncertainty and financial worries, ${ }^{9-11}$ has been associated with increased risk of MVC. Changes in drinking patterns have also occurred during the pandemic. Bars and restaurants were closed for certain periods, due to measures to tackle Covid-19, and had fewer customers when open as people were trying to reduce the risk of catching the virus. However, overall alcohol consumption may have increased. ${ }^{12}$ Sleeping patterns (another risk factor) have also been affected by the pandemic. ${ }^{13-14}$

Empirical evidence on the impact of the Covid-19 pandemic on MVCs is scarce, as many countries publish data with a significant time lag. Early empirical evidence suggests that there has been a decrease in collisions during the pandemic..$^{2,15-18}$ Interestingly, in the USA there has been a reduction in MVCs in the first months of the Covid-19 pandemic, ${ }^{15-16}$ but at the same time there has been an increase in deaths. ${ }^{19}$

The objective of this study is to examine whether and to what extent MVCs, injuries and deaths were affected by the Covid-19 pandemic in Northern Ireland.

\section{Data and Methods}

We obtained monthly data on MVCs from the Police Service of Northern Ireland (PSNI). Data included the monthly number of slight injuries, serious injuries and deaths for the period from January 2015 to October 2020. Unfortunately, monthly data by cause of MVC were not available, but the PSNI provides monthly data on the number of traffic-related fines by type of violation. 
medRxiv preprint doi: https://doi.org/10.1101/2021.01.03.21249173; this version posted January 5, 2021. The copyright holder for this

preprint (which was not certified by peer review) is the author/funder, who has granted medRxiv a license to display the preprint in

It is made available under a CC-BY-NC-ND 4.0 International license .

We investigated the lockdown effects employing Interrupted Time Series (ITS) analysis. The "intervention" started in March, when the first Covid-19 death occurred in Northern Ireland, and the first lockdown was introduced. This is also the period when reduced mobility was observed. ${ }^{20}$ Separate analyses were conducted depending on the MVC outcome: number of slight injuries, serious injuries, and deaths. The model includes a time variable, a post-intervention dummy variable, and an interaction between the post-intervention dummy and the time variable, to capture any change in trend. In particular, for each target series we estimated the model presented in Equation (1).

$$
Y_{t}=\beta_{0}+\beta_{1} t+\beta_{2} D_{t}+\beta_{3}\left(t \times D_{t}\right)+\varepsilon_{t}
$$

where $t$ is the time trend, $D_{t}$ is a dummy variable which takes the value 0 in the pre-lockdown period and the value 1 in the post-lockdown period and $\varepsilon_{t}$ is the error term assuming the standard assumptions hold. $\beta_{0}$ can be interpreted as the overall (baseline) level at time $t=0$, $\beta_{1}$ can be interpreted as the pre-lockdown trend, $\beta_{2}$ indicates the change in the level after the lockdown and $\beta_{3}$ indicates the change in the slope. The above model can be estimated assuming Gaussianity or Poisson (which is the standard approach in population health evaluations where the outcome is a count variable). The extended set of our results includes both approaches as well as the Quasi Poisson which accounts for overdispersion, even if this does not seem to be the case with our data.

\section{Results}

\subsection{Results on the number of collisions, injuries and deaths}

Figure 1 shows trends in MVCs in 2020 and previous years. There is a clear steep decline in the number of slight injuries in March and April 2020 compared to the same months in previous 
medRxiv preprint doi: https://doi.org/10.1101/2021.01.03.21249173; this version posted January 5, 2021. The copyright holder for this

preprint (which was not certified by peer review) is the author/funder, who has granted medRxiv a license to display the preprint in It is made available under a CC-BY-NC-ND 4.0 International license .

years (panel A). The number of slight injuries started increasing after the lockdown but remained below that of previous years throughout the study period. There is also a decrease in the number of serious injuries, although the difference compared to previous years is not as strong as in the case of slight injuries (panel B). Although in January 2020 the number of serious injuries was larger than that in any of the previous five years, this figure remained much lower than previous years' levels during the first lockdown, and below or at the lower end of the distribution in subsequent months. However, there is little or no evidence of any decrease in deaths during the first lockdown or in the following months (panel C).

[Insert Figure 1 here]

We naturally divided our sample in the pre-lockdown period (from January 2015 to February 2020) and the post-lockdown period (from March 2020 to October 2020) and started our exploratory data analysis (EDA) by investigating a simple time scatterplot for the three underlying target series. A first look reveals that there seems to be a slight, and possibly not statistically significant, break in the trend and a change in the direction of the slope for deaths $\left(Y_{1}\right)$. This is more evident for serious injuries $\left(Y_{2}\right)$ and slight injuries $\left(Y_{3}\right)$ where there is a downward shift in the entire line, with a simultaneous change in the slope (Figure 2).

[Insert Figure 2 here]

We extended our EDA by calculating the descriptive statistics for the full sample, as well as the pre- and post- lockdown subsamples (Table 1). Table 1 includes various statistics evaluated across the full, pre- and post- lockdown samples. We compared the means of the pre- and postlockdown samples employing a T-Test allowing for unequal variances. Even this simplified 
medRxiv preprint doi: https://doi.org/10.1101/2021.01.03.21249173; this version posted January 5, 2021. The copyright holder for this

preprint (which was not certified by peer review) is the author/funder, who has granted medRxiv a license to display the preprint in

It is made available under a CC-BY-NC-ND 4.0 International license .

approach indicates that there is a statistically significant decrease in the average level of serious and slight injuries. In particular, serious injuries decreased by $33.89 \%$ on average (from 64.097 to $42.375 ; p$-value $=0.002$ ) and slight injuries decreased by $41.99 \%$ on average (from 699.29 to 405.625; $p$-value $=0.000)$. However, there is no statistically significant change in the number of deaths ( $p$-value $=0.396)$.

[Insert Table 1 here]

Table 2 presents the ITS results for the three dependent variables. There is a simultaneous change in the trend as well as the slope in the post-lockdown periods for serious injuries $\left(\mathrm{Y}_{2}\right)$ and slight injuries $\left(\mathrm{Y}_{3}\right)$. In accordance with the results of the T-Test, there is no statistically significant difference for the Deaths $\left(Y_{1}\right)$ series. However, we have a negative change in the level after the lockdown $\left(\beta_{2}\right)$ and an abrupt increase in the slope $\left(\beta_{3}\right)$ for the Serious Injuries $\left(Y_{2}\right)$ and Slight Injuries $\left(Y_{3}\right)$ series.

[Insert Table 2 here]

Figure A1 in the Appendix illustrates the autocorrelograms of the residuals from the regression of each series. It is evident that there is no autocorrelation or obvious seasonality patterns.

As an additional check, we also calculated an extended set of results including: NeweyWest HAC t-values and confidence intervals; ${ }^{21}$ Poisson distribution for the error term; and Quasi Poisson Distribution to account for overdispersion. Results are presented in Tables A1, $\mathrm{A} 2$ and $\mathrm{A} 3$ respectively, in the Appendix. In all cases, our qualitative conclusions about $\beta_{2}$ and $\beta_{3}$ still hold and confirm the results of the baseline ITS model. 
medRxiv preprint doi: https://doi.org/10.1101/2021.01.03.21249173; this version posted January 5, 2021. The copyright holder for this

preprint (which was not certified by peer review) is the author/funder, who has granted medRxiv a license to display the preprint in

It is made available under a CC-BY-NC-ND 4.0 International license .

\subsection{The potential role of speeding on empty streets}

Interestingly, while there was a steep decline in the number of injuries, there didn't seem to be any change in the number of deaths. Could this be a result of greater collision severity, due to speeding on empty streets $?^{6-7}$ Or could it be a result of increased alcohol consumption? ${ }^{12}$ Figure A2 in the Appendix shows the trends in speeding fines and fines relating to driving under the influence of alcohol or drugs in 2020 and previous years (before 2017 there did not seem to be much testing for alcohol). There is a steep increase in speeding fines in May and June 2020 compared to years 2017-2019. This could be a result of increased traffic violations, or a result of a greater police crackdown as a result of more speeding-related accidents. There didn't seem to be any relative increase in the number of alcohol and drug violations, possibly because people were drinking more at home, as bars and restaurants were shut, or because they were afraid of catching the virus there after they opened.

\section{Discussion}

This study shows that there has been an increase in MVC-related injuries in Northern Ireland during the Covid-19 pandemic. There was a decrease in slight injuries in March-October 2020 (which largely coincided with the first lockdown and other social distancing measures) by about $42 \%$, reflecting reduced mobility during and after the lockdown. ${ }^{20}$ Serious injuries demonstrated a reduction of about $34 \%$ over the same period. However, there was no statistically significant change in the number of deaths as a result of collision. Interestingly, while the total number of collisions was reduced, roughly the same number of people died as would have been expected in the absence of the pandemic - raising interesting questions about collision severity and reduced collision numbers. 
medRxiv preprint doi: https://doi.org/10.1101/2021.01.03.21249173; this version posted January 5, 2021. The copyright holder for this

preprint (which was not certified by peer review) is the author/funder, who has granted medRxiv a license to display the preprint in It is made available under a CC-BY-NC-ND 4.0 International license .

This differential impact on the number of injuries and the number of deaths is likely to be a result of speeding in less congested streets, due to reduced traffic volume during the lockdown and the pandemic in general. Unfortunately, monthly data by cause of MVC were not available. However, an increase in fines for speeding in May and June 2020 points in that direction. Of course, the number of fines is affected by policing intensity - but even if there was a crackdown on speeding particularly in May-June 2020, this would likely be a response to increased speeding violations. Speeding can lead to more severe crashes, thus resulting in death. Therefore, it appears that the negative impact of the reduced number miles travelled was counterbalanced by higher speeds.

Another factor that may have not allowed the number of deaths to decrease is health system capacity during the pandemic. As ambulances and hospitals were responding to large numbers of Covid-19 patients, this may have led to a delay in treatment of MVC injuries, that could lead to more fatalities that otherwise. However, it is important to note that this is just a plausible explanation and this does not follow directly from the findings of this study. Future research can examine whether health system capacity was in any way related to MVC fatalities during the pandemic.

An increase in alcohol consumption reported elsewhere during the pandemic could also have been a factor, ${ }^{12}$ but there was no evidence of an increase in fines relating to drunk driving. It is possible that increased alcohol consumption was counterbalanced by drinking at home rather than in pubs or restaurants, thus avoiding drink driving. It is not possible to examine the role of any change in sleep duration and patterns with the data currently available. This can be examined by future research.

Results of this study add to existing research on how the pandemic affected MVCs. While there is consensus on a reduction in collisions, ${ }^{15-18}$ the results on fatalities are not always in the same direction. ${ }^{2,19}$ 
medRxiv preprint doi: https://doi.org/10.1101/2021.01.03.21249173; this version posted January 5, 2021. The copyright holder for this preprint (which was not certified by peer review) is the author/funder, who has granted medRxiv a license to display the preprint in It is made available under a CC-BY-NC-ND 4.0 International license .

Findings also provide additional evidence on the spillover effects of Covid-19 on other health outcomes in Northern Ireland and elsewhere. ${ }^{22-27}$ Overall, this study highlights yet another indirect consequence of the pandemic in the short run, but as people adapt their behaviour, additional evidence will be needed to study the long-term effects on motor vehicle collisions.

Funding: None

Conflict of interest: None

Ethics approval: The data used were aggregate anonymous data, so ethics approval was not required.

Checklist: There is no relevant checklist of observational studies.

Data availability statement: The data used on collisions are freely available on the website of the Police Service of Northern Ireland.

\section{References}

[1] Police Service of Northern Ireland. 2020. Road Traffic Collision Statistics. Available at: https://www.psni.police.uk/inside-psni/Statistics/road-traffic-collision-statistics/

[2] Vandoros, S. 2021. Covid-19, Lockdowns and Motor Vehicle Collisions: Empirical Evidence from Greece. MedRxiv. doi: https://doi.org/10.1101/2020.12.26.20248883

[3] Chudik A, Mohaddes K, Perasan MH, Raissi M, Rebucci A. 2020. Economic consequences of Covid-19: A counterfactual multi-country analysis. VoxEU. Available at: https://voxeu.org/article/economic-consequences-covid-19-multi-country-analysis

[4] Ruhm CJ. Are recessions good for your health?. Q J Econ. 2000 May 1;115(2):617-50.

[5] Stuckler, D., Basu, S., Suhrcke, M., Coutts, A. and McKee, M., 2011. Effects of the 2008 recession on health: a first look at European data. Lancet, 378(9786), pp.124-125.

[6] Inada, H., Ashraf, L. and Campbell, S., 2020. COVID-19 lockdown and fatal motor vehicle collisions due to speed-related traffic violations in Japan: a time-series study. Injury Prevention. Doi: 10.1136/injuryprev-2020-043947

[7] The Guardian, 2020. UK motorists caught at 'extreme speeds' on quiet lockdown roads. 13 April 2020. Available at: https://www.theguardian.com/world/2020/apr/13/increase-inspeeding-incidents-on-uks-quiet-lockdown-roads

[8] Lagarde, E., Chastang, J.F., Gueguen, A., Coeuret-Pellicer, M., Chiron, M. and Lafont, S., 2004. Emotional stress and traffic accidents: the impact of separation and divorce. Epidemiology, 15(6), pp.762-766. 
medRxiv preprint doi: https://doi.org/10.1101/2021.01.03.21249173; this version posted January 5, 2021. The copyright holder for this preprint (which was not certified by peer review) is the author/funder, who has granted medRxiv a license to display the preprint in It is made available under a CC-BY-NC-ND 4.0 International license.

[9] Vandoros, S., Kavetsos, G. and Dolan, P., 2014. Greasy roads: the impact of bad financial news on road traffic accidents. Risk Analysis, 34(3), pp.556-566.

[10] Vandoros, S., Avendano, M. and Kawachi, I., 2018. The short-term impact of economic uncertainty on motor vehicle collisions. Preventive Medicine, 111, pp.87-93.

[11] Giulietti, C., Tonin, M. and Vlassopoulos, M., 2020. When the market drives you crazy: Stock market returns and fatal car accidents. Journal of health economics, 70, p.102245.

[12] Pollard, M.S., Tucker, J.S. and Green, H.D., 2020. Changes in adult alcohol use and consequences during the COVID-19 pandemic in the US. JAMA network open, 3(9), pp.e2022942-e2022942.

[13] Cellini, N., Canale, N., Mioni, G. and Costa, S., 2020. Changes in sleep pattern, sense of time and digital media use during COVID-19 lockdown in Italy. Journal of Sleep Research, p.e13074.

[14] Leone, M.J., Sigman, M. and Golombek, D.A., 2020. Effects of lockdown on human sleep and chronotype during the COVID-19 pandemic. Current Biology, 30(16), pp.R930-R931.

[15] Sutherland, M., McKenney, M. and Elkbuli, A., 2020. Vehicle related injury patterns during the COVID-19 pandemic: What has changed?. The American Journal of Emergency Medicine.

[16] Doucette, M.L., Tucker, A., Auguste, M.E., Watkins, A., Green, C., Pereira, F.E., Borrup, K.T., Shapiro, D. and Lapidus, G., 2020. Initial impact of COVID-19's stay-at-home order on motor vehicle traffic and crash patterns in Connecticut: an interrupted time series analysis. Injury Prevention. Doi: 10.1136/inuryprev-2020-043945

[17] Calderon-Anyosa, R.J. and Kaufman, J.S., 2020. Impact of COVID-19 lockdown policy on homicide, suicide, and motor vehicle deaths in Peru. Preventive Medicine, p.106331.

[18] Saladié, Ò., Bustamante, E. and Gutiérrez, A., 2020. COVID-19 lockdown and reduction of traffic accidents in Tarragona province, Spain. Transportation research interdisciplinary perspectives, 8 , p.100218.

[19] Meyer, M.W., 2020. COVID Lockdowns, Social Distancing, and Fatal Car Crashes: More Deaths on Hobbesian Highways?. Cambridge Journal of Evidence-Based Policing, pp.1-22.

[20] Google LLC "Google COVID-19 Community Mobility Reports". https://www.google.com/covid19/mobility/ Accessed: 20 December 2020.

[21] Newey, W.K. and West, K.D., 1987. A simple, positive semi-definite, heteroskedasticity and autocorrelation consistent covariance matrix. Econometrica. 55(3), 703-708.

[22] Lai, A.G., Pasea, L., Banerjee, A., Denaxas, S., Katsoulis, M., Chang, W.H., Williams, B., Pillay, D., Noursadeghi, M., Linch, D. and Hughes, D., 2020. Estimating excess mortality in people with cancer and multimorbidity in the COVID-19 emergency. medRxiv. 
medRxiv preprint doi: https://doi.org/10.1101/2021.01.03.21249173; this version posted January 5, 2021. The copyright holder for this preprint (which was not certified by peer review) is the author/funder, who has granted medRxiv a license to display the preprint in It is made available under a CC-BY-NC-ND 4.0 International license

[23] Maringe, C., Spicer, J., Morris, M., Purushotham, A., Nolte, E., Sullivan, R., Rachet, B. and Aggarwal, A., 2020. The impact of the COVID-19 pandemic on cancer deaths due to delays in diagnosis in England, UK: a national, population-based, modelling study. The lancet oncology, 21(8), pp.1023-1034.

[24] Pierce, M., Hope, H., Ford, T., Hatch, S., Hotopf, M., John, A., Kontopantelis, E., Webb, R., Wessely, S., McManus, S. and Abel, K.M., 2020. Mental health before and during the COVID-19 pandemic: a longitudinal probability sample survey of the UK population. The Lancet Psychiatry, 7(10), pp.883-892.

[25] Nomura, S., Kawashima, T., Yoneoka, D., Tanoue, Y., Eguchi, A., Gilmour, S., Kawamura, Y., Harada, N. and Hashizume, M., 2020. Trends in suicide in Japan by gender during the COVID-19 pandemic, up to September 2020. Psychiatry research, p.113622.

[26] Rivera, R., Rosenbaum, J.E. and Quispe, W., 2020. Excess mortality in the United States during the first three months of the COVID-19 pandemic. Epidemiology \& Infection, 148.

[27] Vandoros, S., 2020. Excess Mortality during the Covid-19 pandemic: Early evidence from England and Wales. Social Science \& Medicine, vol.258, p.113101. Doi: 10.1016/j.socscimed.2020.113101 
medRxiv preprint doi: https://doi.org/10.1101/2021.01.03.21249173; this version posted January 5, 2021. The copyright holder for this preprint (which was not certified by peer review) is the author/funder, who has granted medRxiv a license to display the preprint in It is made available under a CC-BY-NC-ND 4.0 International license.

\section{Tables and Figures}



Panel A: Number of slight injuries



Panel B: Number of serious injuries

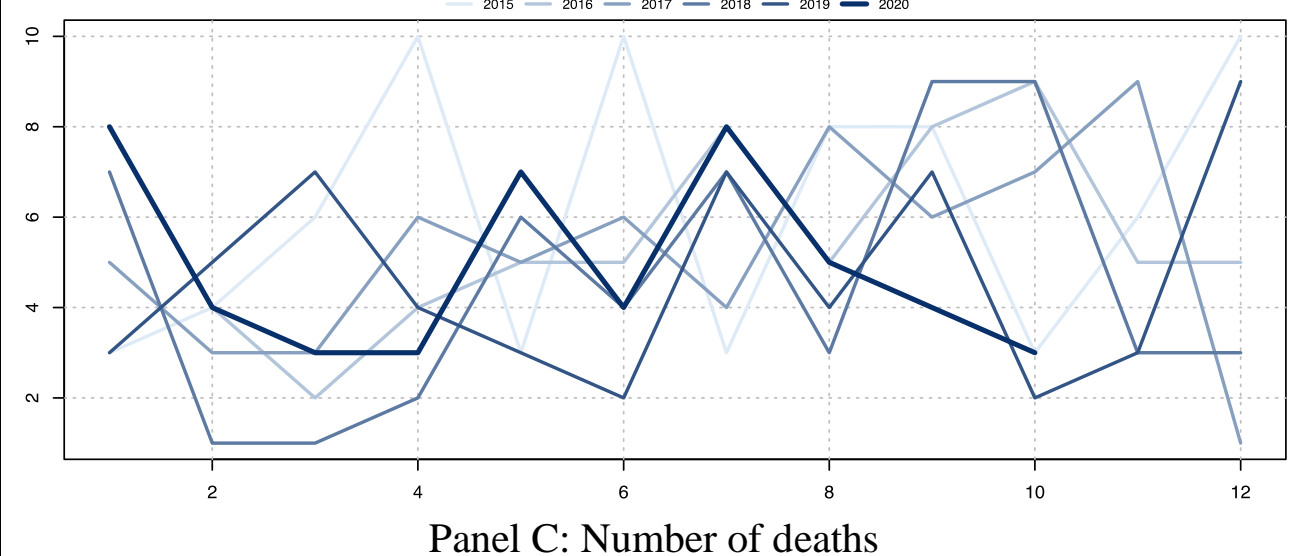

Figure 1 - Trends in Motor Vehicle Collisions in 2020 and previous five years 
medRxiv preprint doi: https://doi.org/10.1101/2021.01.03.21249173; this version posted January 5, 2021. The copyright holder for this preprint (which was not certified by peer review) is the author/funder, who has granted medRxiv a license to display the preprint in It is made available under a CC-BY-NC-ND 4.0 International license.

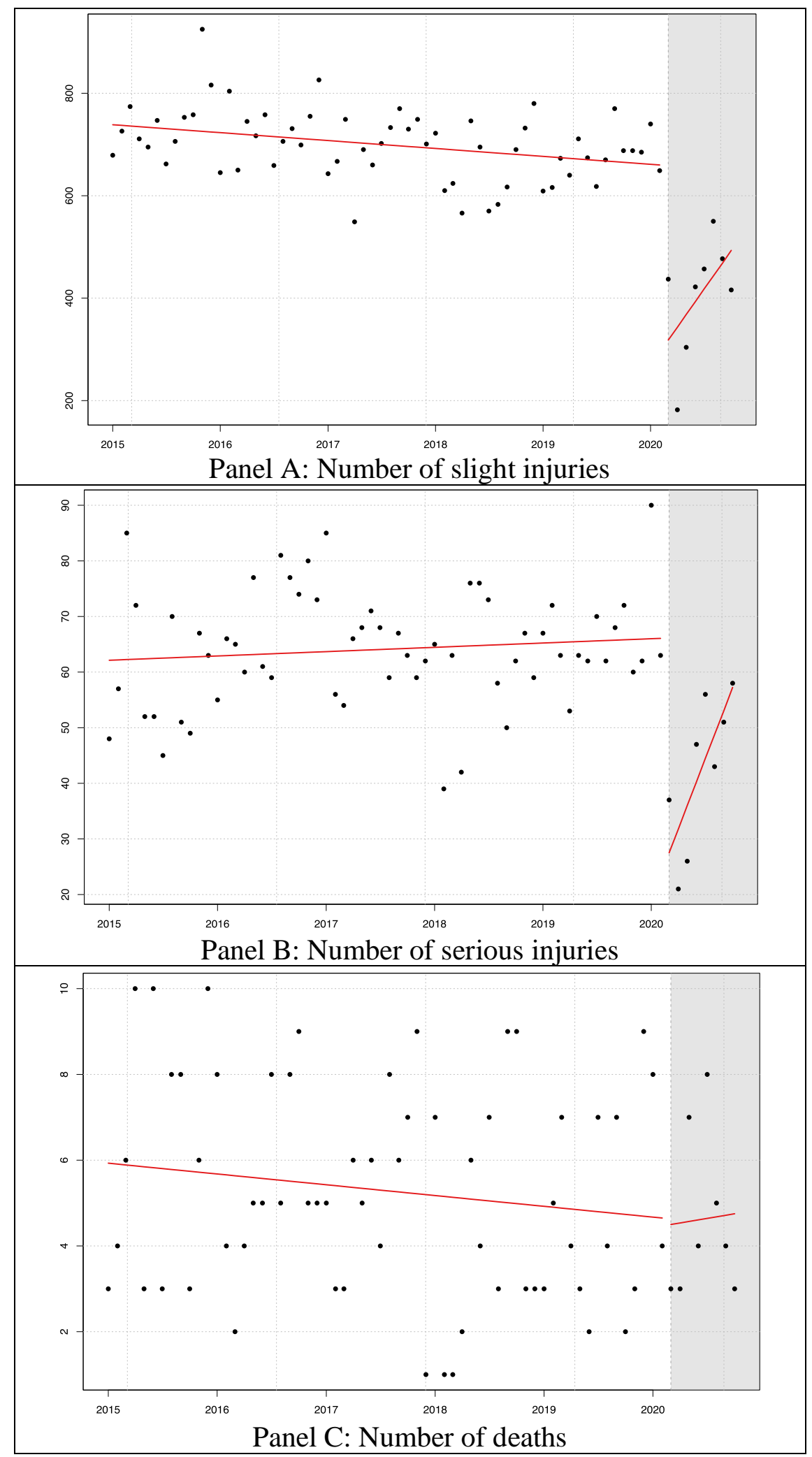

Figure 2 - Scatterplot and trends: Motor Vehicle Collisions in 2020 and previous five years 
medRxiv preprint doi: https://doi.org/10.1101/2021.01.03.21249173; this version posted January 5, 2021. The copyright holder for this preprint (which was not certified by peer review) is the author/funder, who has granted medRxiv a license to display the preprint in It is made available under a CC-BY-NC-ND 4.0 International license.

Table 1 - Descriptive Statistics

\begin{tabular}{lccccccccc}
\hline & \multicolumn{3}{c}{ Deaths $\left(Y_{1}\right)$} & \multicolumn{4}{c}{ Serious Injuries $\left(Y_{2}\right)$} & \multicolumn{3}{c}{ Slight Injuries $\left(Y_{3}\right)$} \\
\hline & Full & Pre & Post & Full & Pre & Post & Full & Pre & Post \\
\hline Observations & 70 & 62 & 8 & 70 & 62 & 8 & 70 & 62 & 8 \\
Sample Mean & 5.214 & 5.290 & 4.625 & 61.614 & 64.097 & 42.375 & 665.729 & 699.290 & 405.625 \\
T-Test (pval) & & 0.396 & & & $\mathbf{0 . 0 0 2}$ & & & $\mathbf{0 . 0 0 0}$ & \\
Std. Dev. & 2.443 & 2.505 & 1.923 & 12.765 & 10.417 & 13.522 & 119.376 & 67.986 & 113.562 \\
Min & 1 & 1 & 3 & 21 & 39 & 21 & 182 & 549 & 182 \\
Median & 5 & 5 & 4 & 62.5 & 63 & 45 & 690 & 700 & 429.5 \\
Max & 10 & 10 & 8 & 90 & 90 & 58 & 925 & 925 & 550 \\
Skewness & 0.272 & 0.204 & 0.678 & -0.588 & 0.033 & -0.365 & -1.544 & 0.273 & -0.742 \\
Kurtosis & -1.030 & -1.079 & -1.328 & 0.929 & -0.047 & -1.573 & 3.547 & 0.775 & -0.688 \\
\hline
\end{tabular}

Table 2 - Results of the interrupted time series analysis - Gaussian

\begin{tabular}{|c|c|c|c|}
\hline \multirow{3}{*}{$\hat{\beta}_{0}$} & $Y_{1}$ & $Y_{2}$ & $Y_{3}$ \\
\hline & 5.950 & 62.063 & 739.866 \\
\hline & $\begin{array}{r}{[4.687,7.214]} \\
\mathbf{p}=\mathbf{0 . 0 0 0}\end{array}$ & $\begin{array}{r}{[56.755,67.371]} \\
\mathbf{p}=\mathbf{0 . 0 0 0}\end{array}$ & $\begin{array}{r}{[704.515,775.216]} \\
\mathbf{p}=\mathbf{0 . 0 0 0}\end{array}$ \\
\hline \multirow[t]{2}{*}{$\hat{\beta}_{1}$} & -0.021 & 0.065 & -1.288 \\
\hline & $\begin{array}{r}{[-0.056,0.014]} \\
\mathrm{p}=0.235\end{array}$ & $\begin{array}{r}{[-0.082,0.211]} \\
\mathrm{p}=0.382\end{array}$ & $\begin{array}{r}{[-2.264,-0.312]} \\
\mathbf{p}=\mathbf{0 . 0 1 0}\end{array}$ \\
\hline \multirow[t]{2}{*}{$\hat{\beta}_{2}$} & -3.700 & -302.313 & -1997.532 \\
\hline & $\begin{array}{r}{[-54.174,46.774]} \\
\mathrm{p}=0.884\end{array}$ & $\begin{array}{r}{[-514.364,-90.262]} \\
\mathbf{p}=\mathbf{0 . 0 0 6}\end{array}$ & $\begin{array}{r}{[-3409.659,-585.406]} \\
\mathbf{p}=\mathbf{0 . 0 0 6}\end{array}$ \\
\hline \multirow[t]{2}{*}{$\hat{\beta}_{3}$} & 0.057 & 4.185 & 26.300 \\
\hline & $\begin{array}{r}{[-0.702,0.816]} \\
\mathrm{p}=0.882\end{array}$ & $\begin{array}{r}{[0.996,7.375]} \\
\mathbf{p}=\mathbf{0 . 0 1 1}\end{array}$ & $\begin{array}{r}{[5.062,47.538]} \\
\mathbf{p}=\mathbf{0 . 0 1 6}\end{array}$ \\
\hline $\mathrm{N}$ & 70 & 70 & 70 \\
\hline $\mathrm{R}^{2}$ & 0.029 & 0.372 & 0.682 \\
\hline
\end{tabular}


medRxiv preprint doi: https://doi.org/10.1101/2021.01.03.21249173; this version posted January 5, 2021. The copyright holder for this preprint (which was not certified by peer review) is the author/funder, who has granted medRxiv a license to display the preprint in It is made available under a CC-BY-NC-ND 4.0 International license.

\section{APPENDIX}

Table A1. Gaussian regression with HAC confidence intervals

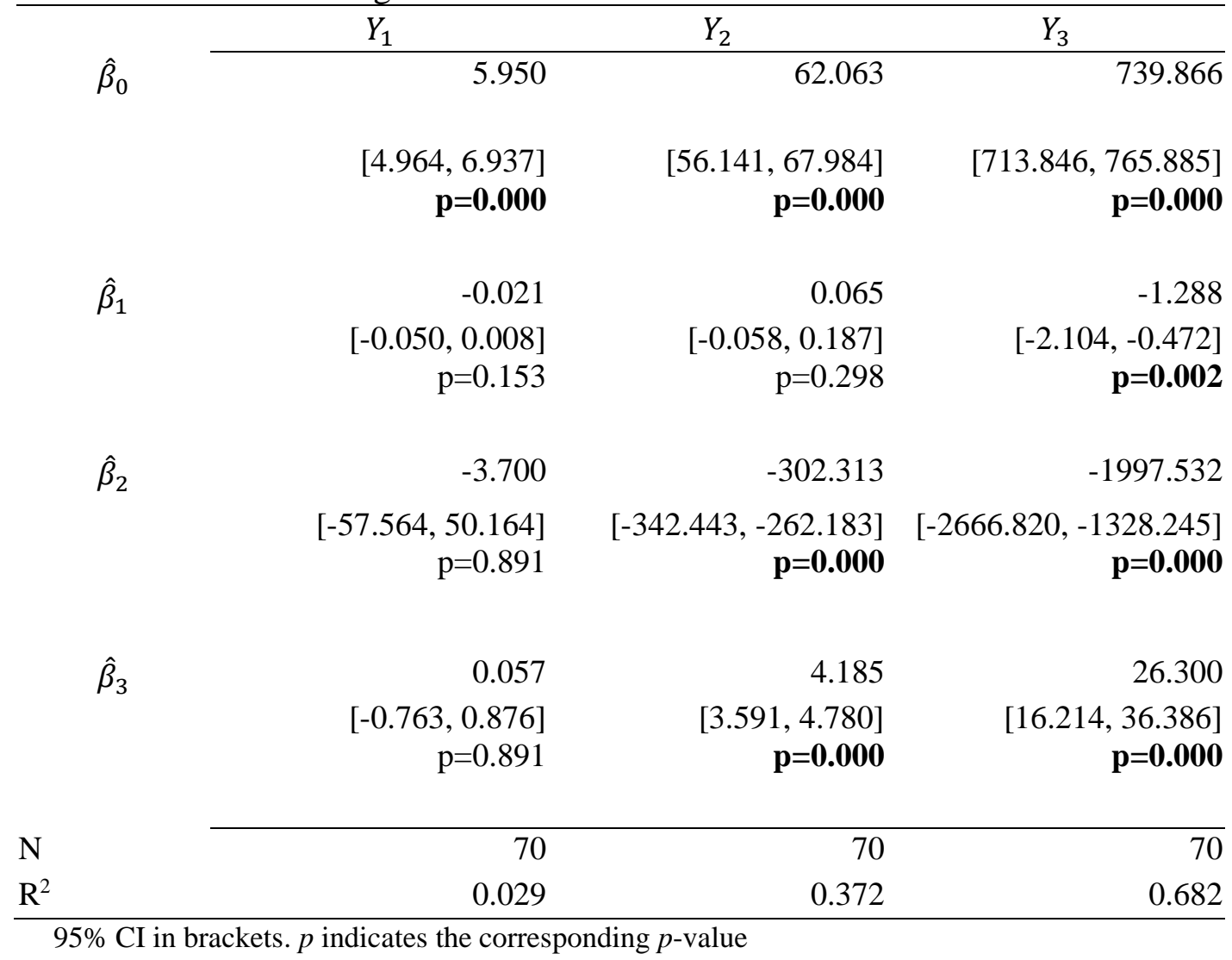


medRxiv preprint doi: https://doi.org/10.1101/2021.01.03.21249173; this version posted January 5, 2021. The copyright holder for this preprint (which was not certified by peer review) is the author/funder, who has granted medRxiv a license to display the preprint in It is made available under a CC-BY-NC-ND 4.0 International license.

Table A2. Poisson Regression

\begin{tabular}{|c|c|c|c|}
\hline \multirow{4}{*}{$\hat{\beta}_{0}$} & $Y_{1}$ & $Y_{2}$ & $Y_{3}$ \\
\hline & 1.788 & 4.128 & 6.608 \\
\hline & {$[1.576,2.001]$} & {$[4.065,4.192]$} & {$[6.589,6.626]$} \\
\hline & & & \\
\hline \multirow[t]{3}{*}{$\hat{\beta}_{1}$} & -0.004 & 0.001 & -0.002 \\
\hline & {$[-0.010,0.002]$} & {$[-0.001,0.003]$} & {$[-0.002,-0.001]$} \\
\hline & $\mathrm{p}=0.200$ & $\mathrm{p}=0.256$ & $p=0.000$ \\
\hline \multirow[t]{3}{*}{$\hat{\beta}_{2}$} & -0.770 & -7.152 & -4.730 \\
\hline & {$[-10.137,8.596]$} & {$[-10.321,-3.984]$} & {$[-5.740,-3.719]$} \\
\hline & $\mathrm{p}=0.872$ & $p=0.000$ & $\mathbf{p}=\mathbf{0 . 0 0 0}$ \\
\hline \multirow[t]{3}{*}{$\hat{\beta}_{3}$} & 0.012 & 0.100 & 0.064 \\
\hline & {$[-0.129,0.152]$} & {$[0.053,0.148]$} & {$[0.049,0.079]$} \\
\hline & $\mathrm{p}=0.871$ & $p=0.000$ & $p=0.000$ \\
\hline $\mathrm{N}$ & 70 & 70 & 70 \\
\hline
\end{tabular}

Table A3. Quasi Poisson Regression

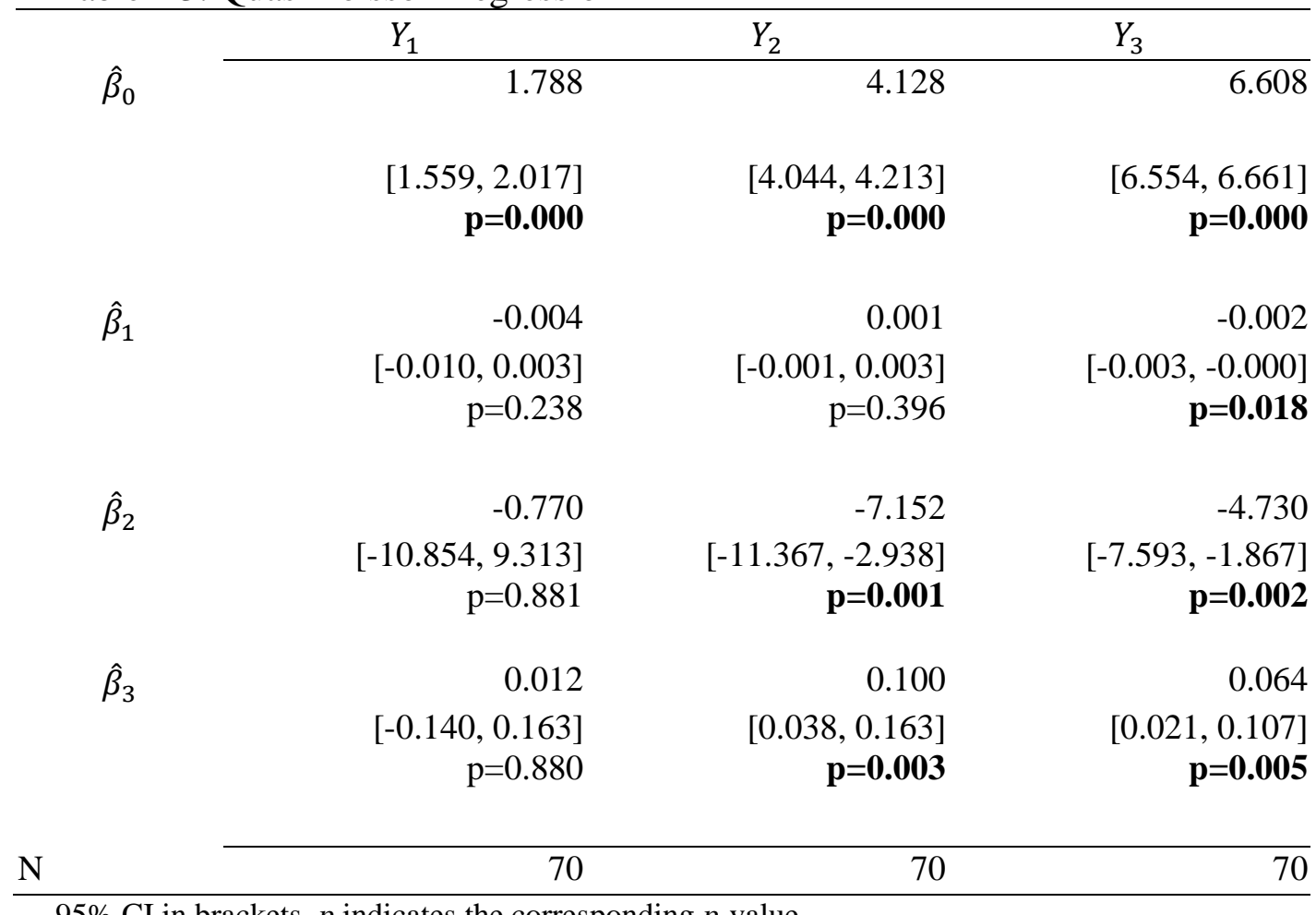

95\% CI in brackets. $p$ indicates the corresponding $p$-value 
medRxiv preprint doi: https://doi.org/10.1101/2021.01.03.21249173; this version posted January 5, 2021. The copyright holder for this preprint (which was not certified by peer review) is the author/funder, who has granted medRxiv a license to display the preprint in It is made available under a CC-BY-NC-ND 4.0 International license.

Deaths



Serious Injuries

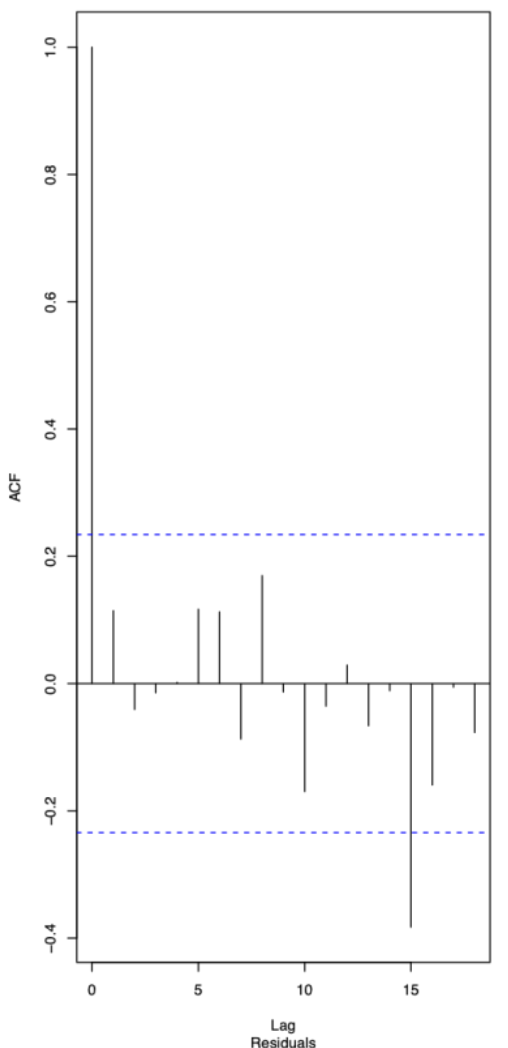

Figure A1 - Regression residuals

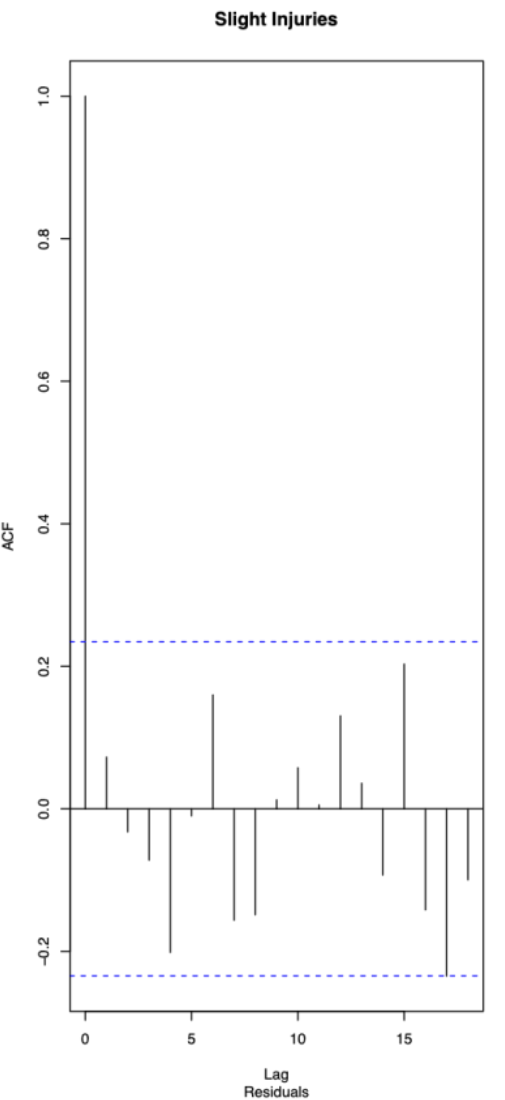

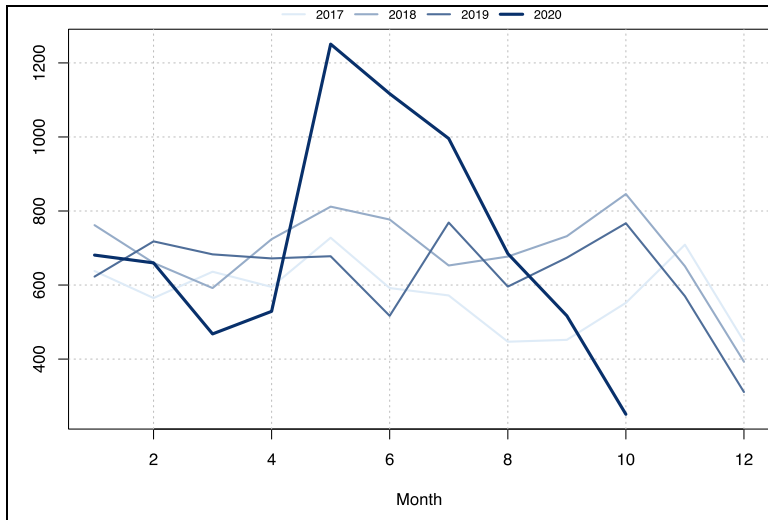

Panel A: Monthly number of fines for driving under the influence of alcohol or drugs

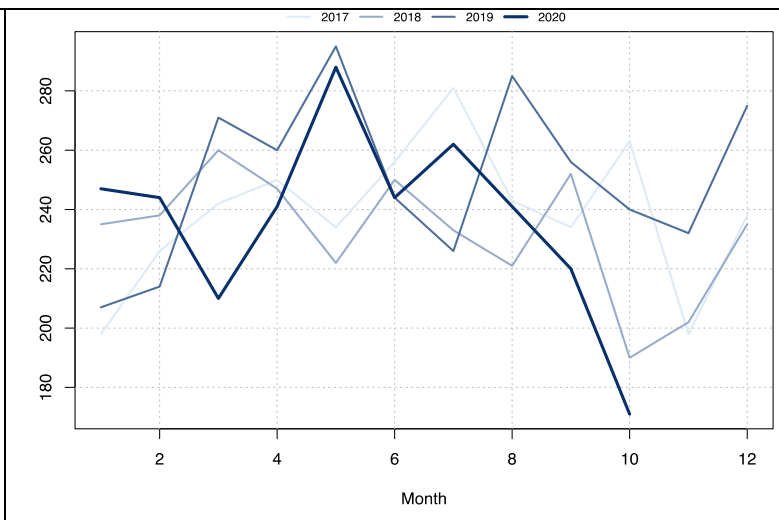

Panel B: Monthly number of fines for driving under the influence of alcohol or drugs

Figure A2 - Monthly number of fines for speeding and driving under the influence of alcohol or drugs, years 2017-2020, Northern Ireland 